Check for updates

1 University of Massachusetts Lowell, MA, USA

2 Johns Hopkins School of Medicine and Johns Hopkins Berman Institute of Bioethics, Baltimore, USA

3 Georgetown University, Washington, DC, USA

4 Richard M Fairbanks School of Public Health and Robert H McKinney School of Law, Indiana University, Indianapolis, USA

Correspondence to: N G Evans Nicholas_evans@uml.edu Cite this as: BMJ2021;373:n1631 http://dx.doi.org/10.1136/bmj.n1631 Published: 29 June 2021

\section{Covid-19, equity, and inclusiveness}

\section{Our woeful record so far must be turned around fast}

\section{Nicholas G Evans, ${ }^{1}$ Zackary D Berger, ${ }^{2}$ Alexandra L Phelan, ${ }^{3}$ Ross D Silverman ${ }^{4}$}

In March 2020, as cases of covid-19 spiked around the world, we set out the requirements for an equitable response. We argued that honest, transparent communication on patients' terms was vital; that free covid-19 testing and equitable sharing of health resources were essential to public health; that social distancing needed to be coupled with community support; and for robust sick leave policies for employees with covid-19 and paid time off for those affected by shutdowns. We argued congregate settings such as correctional institutions, homeless shelters, and refugee camps should be reconsidered where possible and adequately supported when necessary. Finally, we argued for adequate mental healthcare for essential workers and their families. ${ }^{1}$

The story of equity in covid-19, however, is a story of failure. Systems guaranteeing access to testing remain absent; in the US, despite major legislation, even patients with health insurance can still incur substantial costs for testing or be unable to physically access testing locations. ${ }^{2}$ Hoarding of health resources continues, most notably of vaccines by high income nations at the expense of everyone else. ${ }^{3}$ Sick leave policies remain inadequate while workers have seen an $8.8 \%$ global loss in working hours from unemployment, inactivity, and reduced working hours. ${ }^{4}$

Women, particularly those from marginalised communities, are disproportionally affected by loss of paid work and further burdened by increased unpaid labour, while at the same time making up most of the healthcare workforce.$^{5}$ Congregate settings, in particular food processing plants, prisons, and detention centres, remain critical sites of transmission, illness, and death. ${ }^{6}$ Although some attempts have been made to mitigate the pandemic's toll on mental health, efforts have been inconsistent, under-resourced, and may not target the most vulnerable groups. ${ }^{7}$ UN Women (the UN body for gender equality and the empowerment of women) has described increased violence against women and girls as a "shadow pandemic" exacerbated by both the effects of, and control measures for, covid-19.

These ongoing inequities are grounded in the historical marginalisation of communities and neglect of community health. In the context of this pandemic, however, they risk reinforcing disparities between those who survive this pandemic with affluence intact, and those who-even if they do not become infected-may be permanently disadvantaged and harmed by the lack of action to protect vulnerable people.

The arrival of vaccines will not relieve these inequities and may even exacerbate them. When, where, and how someone gets vaccinated are mediated by structural and systemic factors that created inequities in previous phases of the pandemic. People with limited or no internet connectivity are unable to access vaccine appointment websites, while those employed in (often low paid) service work may be unable to take time off to get vaccinated.

Increasing state and business interest in vaccine and immunity passports suggests we may be heading towards a time when ability to work, access goods and services, or even move within society will be contingent on vaccination or immunity. Those least able to access vaccines will once again be harmed most by the inequities of the pandemic response. ${ }^{8}$ The situation may become even more dire as high income countries continue their vaccine nationalism, enabling their economies to rebound while denying low and middle income countries vaccines for essential workers and vulnerable groups.

\section{Starting now}

It is not too late to start helping struggling individuals, communities, and countries through this pandemic. Given the real possibility of further covid-19 waves, even in countries where vaccines are lowering transmission, ${ }^{9}$ we need to ensure case counts stay low by giving people the resources they need to maintain social distance and eliminating contexts that increase transmission. As US states set up vaccine lotteries and scholarships ${ }^{10}$ instead of investing in equitable access and pandemic resilience, we must continue to push for these structural supports.

Yet supportive measures are only part of the solution. Pandemic resilience requires repairing or restoring individuals and communities who have experienced severe loss or deprivation from mismanaged or ill applied control measures; have lost access to their basic needs through government negligence; or who contracted covid-19 because a lack of equitable control measures forced them into high risk situations. This also should include the substantial population with long term symptoms from covid.

Calls have already been made for covid-19 reparations, ${ }^{11}$ and for a covid-19 truth and reconciliation process. ${ }^{12}$ Without reparation, we risk creating a covid-19 underclass of people who will never recover from the pandemic. Without truth and reconciliation, we risk failing to account for the full scope of the harm of this pandemic, leaving communities even less prepared for the next one.

Without change, preventable domestic and global inequities will persist, perhaps for many generations, to the detriment of communities, national economies, and even global stability. Given the potential for this crisis to endure for years, we owe it to each other to 
ensure that all control measures become equitable and inclusive, and to find justice for the victims we have already created.

Competing interests: We have read and understood BMJ policy on declaration of interests and have no interests to declare.

Provenance and peer review: Commissioned; not externally peer reviewed.

1 Berger ZD, Evans NG, Phelan AL, Silverman RD. Covid-19: control measures must be equitable and inclusive. BM/2020;368:m1141. doi: 10.1136/bmj.m1141. pmid: 32198146

2 Kurani N, Pollitz K, Cotliar D, Shanosky N, Cox C. Covid-19 test prices and payment policy. 29 Mar 2021. https://www.healthsystemtracker.org/brief/covid-19-test-prices-and-payment-policy/

3 Yamey G. Rich countries should tithe their vaccines. Nature 2021;590:529. doi: 10.1038/d41586-021-00470-9. pmid: 33627806

4 Hsiang S, Allen D, Annan-Phan S, etal. The effect of large-scale anti-contagion policies on the COVID-19 pandemic. Nature2020;584:262-7. doi: 10.1038/541586-020-2404-8. pmid: 32512578

5 Salles A. Covid has worsened gender disparities, especially for women of color. Here's what we can do now to turn the tide. Stanford University Clayman Institute for Gender Research, 2021. https://gender.stanford.edu/news-publications/gender-news/covid-has-worsened-gender-disparities-especially-women-color-heres

6 Franco-Paredes C, Ghandnoosh N, Latif H, etal. Decarceration and community re-entry in the COVID-19 era. Lancet Infect Dis 2021;21:e11-6. doi: 10.1016/S1473-3099(20)30730-1. pmid: 33007225

7 De Kock JH, Latham HA, Leslie SJ, etal. A rapid review of the impact of COVID-19 on the mental health of healthcare workers: implications for supporting psychological well-being. BMC Public Health 2021;21:104. doi: 10.1186/s12889-020-10070-3. pmid: 33422039

8 Phelan AL. COVID-19 immunity passports and vaccination certificates: scientific, equitable, and legal challenges. Lancet 2020;395:1595-8. doi: 10.1016/S0140-6736(20)31034-5. pmid: 32380041

9 Thompson MG, Burgess JL, Naleway AL, etal. Interim estimates of vaccine effectiveness of BNT162b2 and MRNA-1273 covid-19 vaccines in preventing SARS-CoV-2 infection among health care personnel, first responders, and other essential and frontline workers - eight US locations, December 2020-March 2021. MMWR Morb Mortal Wkly Rep 2021;70:495-500.

10 Lynch HF, Largent E. Is it OK to offer a shot at lottery money to get people vaccinated? As bioethicists, we say yes. Philadelphia Inquirer 2021 May 24. https://www.inquirer.com/opinion/commentary/vaccine-lottery-payments-hesitancy-20210524.html

11 Rosenthal MS, Caplan A. How to make it right: covid reparations. Hastings Center blog,15 Mar 2021. https://www.thehastingscenter.org/how-to-make-it-right-covid-reparations/

12 Sabatello M, Jackson Scroggins M, Goto G, etal. Structural racism in the covid-19 pandemic: moving forward. Am J Bioeth 2021;21:56-74.

doi: 10.1080/15265161.2020.1851808 pmid: 33345745

This article is made freely available for use in accordance with BMJ's website terms and conditions for the duration of the covid-19 pandemic or until otherwise determined by BMJ. You may use, download and print the article for any lawful, non-commercial purpose (including text and data mining) provided that all copyright notices and trade marks are retained. 